\title{
$\beta$-Amyloid-Induced Synthesis of the Ganglioside Gd3 Is a Requisite for Cell Cycle Reactivation and Apoptosis in Neurons
}

\author{
Agata Copani, ${ }^{1}$ Daniela Melchiorri, ${ }^{3}$ Andrea Caricasole, ${ }^{3}$ Francesca Martini,, Patrizio Sale, ${ }^{4}$ Roberto Carnevale, ${ }^{4}$ \\ Roberto Gradini, ${ }^{4}$ Maria Angela Sortino, ${ }^{2}$ Luisa Lenti, ${ }^{4}$ Ruggero De Maria, ${ }^{5}$ and Ferdinando Nicoletti ${ }^{3,6}$ \\ Departments of ${ }^{1}$ Pharmaceutical Sciences and ${ }^{2}$ Experimental and Clinical Pharmacology, University of Catania, 95125 \\ Catania, Italy, Departments of ${ }^{3 H u m a n}$ Physiology and Pharmacology and ${ }^{4}$ Experimental Medicine and Pathology, \\ University of Rome "La Sapienza," 00185 Rome, Italy, "Laboratory of Hematology and Oncology, Istituto Superiore di \\ Sanità, 00185 Rome, Italy, and 6I.N.M. Neuromed, 86077 Pozzilli, Italy
}

We have shown that cortical neurons challenged with toxic concentrations of $\beta$-amyloid peptide $(\beta A P)$ enter the S phase of the cell cycle before apoptotic death. Searching for a signaling molecule that lies at the border between cell proliferation and apoptotic death, we focused on the disialoganglioside GD3. Exposure of rat cultured cortical neurons to $25 \mu \mathrm{M} \beta A \mathrm{P}(25-35)$ induced a substantial increase in the intracellular levels of GD3 after $4 \mathrm{hr}$, a time that precedes neuronal entry into $\mathrm{S}$ phase. GD3 levels decreased but still remained higher than in the control cultures after $16 \mathrm{hr}$ of exposure to $\beta A P(25-35)$. Confocal microscopy analysis showed that the GD3 synthesized in response to $\beta A P$ colocalized with nuclear chromatin. The in- crease in GD3 was associated with a reduction of sphingomyelin (the main source of the ganglioside precursor ceramide) and with the induction of $\alpha-2,8$-sialyltransferase (GD3 synthase), the enzyme that forms GD3 from the monosialoganglioside GM3. A causal relationship between GD3, cell-cycle activation, and apoptosis was demonstrated by treating the cultures with antisense oligonucleotides directed against GD3 synthase. This treatment, which reduced $\beta \mathrm{AP}(25-35)$-stimulated GD3 formation by $\sim 50 \%$, abolished the neuronal entry into the $S$ phase and was protective against $\beta \mathrm{AP}(25-35)$-induced apoptosis.

Key words: Alzheimer's disease; $\beta$-amyloid; cell cycle; ganglioside GD3; apoptosis; neurodegeneration
It is currently believed that neuronal degeneration in Alzheimer's disease $(\mathrm{AD})$ is caused by extracellular $\beta$-amyloid peptide ( $\beta \mathrm{AP})$ (for review, see Selkoe, 2001). Cultured neurons exposed to $\beta A P$ predominantly show an apoptotic phenotype (Forloni et al., 1993; Loo et al., 1993), although neuronal apoptosis by $\beta$-amyloid is not the only factor that contributes to the pathophysiology of $\mathrm{AD}$ (Behl, 2000; Mattson, 2000; Joseph et al., 2001; Roth, 2001; Small et al., 2001). Molecular determinants of $\beta$ AP-induced neuronal death have been investigated extensively, but they are still poorly defined. In vivo and in vitro studies have shown that an untimely activation of a cell cycle in terminally differentiated neurons may be a requisite antecedent to neuronal apoptosis in AD (Herrup and Busser, 1995; Vincent et al., 1996; Arendt et al., 1998; Busser et al., 1998; Nagy et al., 1998; Copani et al., 1999; Giovanni et al., 1999, 2000; McShea et al., 1999; Yang et al., 2001). We have shown that full-length $\beta$ AP (fragment 1-42) and its active fragments $\beta \mathrm{AP}(1-40)$ and $\beta \mathrm{AP}(25-35)$ promote the activation of a cell cycle in differentiated cultured cortical neurons. In particular, $\beta$ AP-treated cortical neurons express the repertoire of proteins necessary to exit quiescence and eventually enter $S$ phase. These neurons undergo apoptosis before entering the $\mathrm{G}_{2} / \mathrm{M}$ phase (Copani et al., 1999).

Because $\beta$ AP-induced activation of this "neuronal cycle" seems to be critical for the development of apoptosis, it becomes

\footnotetext{
Received Jan. 9, 2002; revised Feb. 22, 2002; accepted Feb. 26, 2002.

This work was supported by Ministero dell' Istruzione, dell' Universitá e della Ricerca cofin 2000 (M.A.S.), by Ricerca Finalizzata 2000 (F.N.), and by Alzheimer's Association Grant IIRG-01-2824 (A.C.).

Correspondence should be addressed to Dr. Agata Copani, Department of Pharmaceutical Sciences, University of Catania, Viale A. Doria 6, 95125 Catania, Italy. E-mail: acopani@katamail.com.

Copyright (C) 2002 Society for Neuroscience $\quad 0270-6474 / 02 / 223963-06 \$ 15.00 / 0$
}

important to disclose the signaling pathway(s) leading to reactivation of the cell cycle in neurons.

Gangliosides, sialic acid-containing glycosphingolipids, constitute a signaling system involved in the modulation of processes of neuronal proliferation and differentiation. GD3 is highly expressed in the embryonic nervous system, particularly in neuroprogenitor cells. GD3 levels are low in the adult brain (Percy et al., 1991; Svennerholm et al., 1991; Goldman and Reynolds, 1996; Kawai et al., 1998), although they increase in the brains of patients with AD (Kalanj et al., 1991) and Creutzfeldt-Jakob disease (Ando et al., 1984). Interestingly, endogenous GD3 neosynthesis is associated with the appearance of a tumor phenotype in melanocytes (Birkle et al., 2000), and overexpression of GD3 synthase (the $\alpha$-2,8-sialyltransferase that generates GD3 from GM3) enhances the proliferation rate of both rat C6 glioma (Sottocornola et al., 1998) and PC12 pheochromocytoma cell lines (Fukumoto et al., 2000). Thus, it appears that GD3 is able to modify the cell proliferation status under physiological and pathological conditions.

In the present study we show that mature rat cortical neurons in culture, which respond to $\beta$ AP by re-entering the cell cycle, show an early increase in the intracellular levels of GD3. GD3 synthesis in $\beta \mathrm{AP}$-treated neurons is required for their entrance into the $\mathrm{S}$ phase and contributes to the development of apoptosis.

\section{MATERIALS AND METHODS}

Pure neuronal culture. Cultures of pure cortical neurons were obtained from rats at embryonic day 15 as described previously (Copani et al., 1999). Briefly, dissociated cortical cells were plated in a medium consisting of DMEM/Ham's F12 (1:1) supplemented with the following components: $10 \mathrm{mg} / \mathrm{ml}$ bovine serum albumin, $10 \mu \mathrm{g} / \mathrm{ml}$ insulin, $100 \mu \mathrm{g} / \mathrm{ml}$ transferrin, $100 \mu \mathrm{M}$ putrescine, $20 \mathrm{~nm}$ progesterone, $30 \mathrm{~nm}$ selenium, 2 
$\mathrm{mm}$ glutamine, $6 \mathrm{mg} / \mathrm{ml}$ glucose, $50 \mathrm{U} / \mathrm{ml}$ penicillin, and $50 \mu \mathrm{g} / \mathrm{ml}$ streptomycin. Cortical cells were plated at a density of $2 \times 10^{6}$ cells/dish on $35 \mathrm{~mm}$ Nunc (Roskilde, Denmark) dishes precoated with $0.1 \mathrm{mg} / \mathrm{ml}$ poly-D-lysine. Cytosine- $\beta$-D-arabinofuranoside $(10 \mu \mathrm{M})$ was added to the cultures $18 \mathrm{hr}$ after plating to avoid the proliferation of non-neuronal elements and was kept for $3 \mathrm{~d}$ before medium replacement. This method yields $>99 \%$ pure neuronal cultures, as judged by immunocytochemistry for glial fibrillary acidic protein and neuron-specific microtubuleassociated protein 2 (Copani et al., 1999). $\beta$ AP has always been applied to mature cultures at $8 \mathrm{~d}$ in vitro (DIV).

Handling of $\beta$-amyloid peptide. $\beta \mathrm{AP}(25-35)$ and the reverse peptide $\beta A P(35-25)$ were purchased from Bachem AG (Bubendorf, Switzerland). Different lots of peptides were used. $\beta \mathrm{AP}(25-35)$ and $\beta \mathrm{AP}(35-25)$ were solubilized in sterile, doubly distilled water at an initial concentration of $2.5 \mathrm{~mm}$ and stored frozen at $-20^{\circ} \mathrm{C}$. They were used at a final concentration of $25 \mu \mathrm{M}$ in the presence of the glutamate receptor antagonists MK-801 $(10 \mu \mathrm{M})$ and DNQX $(30 \mu \mathrm{M})$ to prevent the excitotoxicity mediated by endogenous glutamate (Copani et al., 1999).

Addition of antisense oligonucleotides to the cultures. Cultures were also treated with the following "end-capped" phosphorothioate antisense oligonucleotides directed against the enzyme $\alpha$-2,8-sialyltransferase (GD3 synthase): 5'-CAGTACAGCCATGGCCCCTCT-3'. A scrambled oligonucleotide was used as a control: 5'-CGACCTACCTATGCGCTACCG-3'. Oligonucleotides $(3 \mu \mathrm{M})$ were applied to the cultures $16 \mathrm{hr}$ before the addition of $\beta \mathrm{AP}(25-35)$.

Fluorescence-activated cell sorter analysis. Fluorescence-activated cell sorter analysis was performed as described previously (Copani et al., 1999). Cells were harvested by incubation with $0.25 \%$ trypsin for 3 min, and the suspension was centrifuged at low speed after addition of $50 \%$ fetal calf serum. Each pellet was washed with PBS and finally fixed in $70 \%$ ethanol. Before staining with propidium iodide $(50 \mu \mathrm{g} / \mathrm{ml}$ in the dark for $30 \mathrm{~min}$ ), suspended cells were treated for $1 \mathrm{hr}$ at $37^{\circ} \mathrm{C}$ with RNase $(100 \mu \mathrm{g} / \mathrm{ml})$. The DNA content and ploidy were assessed using a Coulter Elite flow cytometer (Beckman, Fullerton, CA). The Multicycle AV software program (Phoenix Flow Systems, San Diego, CA) was used to analyze cell-cycle distribution profiles.

Evaluation of sphingomyelin hydrolysis. Cortical neurons were incubated in the presence of $\left[{ }^{3} \mathrm{H}\right]$ serine (specific activity, $26 \mathrm{Ci} \mathrm{mmol}^{-1}$; Amersham Biosciences, Milan, Italy) for $72 \mathrm{hr}$ before exposure to $\beta \mathrm{AP}(25-35)$ for $4 \mathrm{hr}$. The reaction was stopped by adding methanol: chloroform: $\mathrm{HCl}(100: 100: 1, \mathrm{v} / \mathrm{v} / \mathrm{v})$ and a balanced salt solution containing $10 \mathrm{~mm}$ EDTA; the aqueous and lipid phases were separated by centrifugation. Glycerophospholipids present in the lipid phase were saponified in methanolic $\mathrm{KOH}\left(0.1 \mathrm{M}\right.$ for $1 \mathrm{hr}$ at $\left.37^{\circ} \mathrm{C}\right)$ before resolution of sphingomyelin by sequential one-dimensional TLC, using chloroform: benzene:ethanol $(80: 40: 75, \mathrm{v} / \mathrm{v} / \mathrm{v})$ followed by chloroform:methanol:28\% ammonia $(65: 25: 5, \mathrm{v} / \mathrm{v} / \mathrm{v})$ as solvents. Plates were analyzed using a digital autoradiographer (Berthold, Bad Wildbad, Germany).

Assessment of intracellular GD3 levels. Cultures were washed twice with

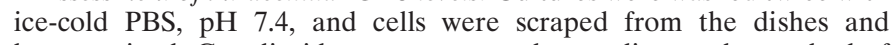
homogenized. Gangliosides were extracted according to the method of Svennerholm and Fredman (1980) as described previously (Dotta et al., 1998) and analyzed by high-performance TLC (HPTLC) using analytical precoated Silica gel 60 HPTLC plates (Merck, Darmstadt, Germany). All plates were first activated by heating to $100^{\circ} \mathrm{C}$ for $30 \mathrm{~min}$. Samples were spotted onto plates with a Hamilton syringe in chloroform:methanol:0.25\% KCl (5:4:1, v/v/v). Authentic GD3 (provided by Fidia S.p.A., Abano Terme, Italy) was used as standard. GD3 was immunodetected by using the R24 anti-GD3 monoclonal antibody (1:100). The plates were incubated for $1 \mathrm{hr}$ at room temperature with the primary antibody, washed twice with PBS-Tween 20, and then incubated for $45 \mathrm{~min}$ at room temperature with a horseradish peroxidase-conjugated rabbit antimouse antibody (1:200; Sigma, St. Louis, MO). Detection was performed by ECL (Amersham Biosciences). The bands were quantified by scanning densitometric analysis.

Immunofluorescence analysis of GD3. Cultures were fixed with $2 \%$ paraformaldehyde. After incubation with $3 \%$ nonimmunized mouse serum in PBS, the R24 anti-GD3 monoclonal antibody (1:100) was applied at $4^{\circ} \mathrm{C}$ for $72 \mathrm{hr}$. Cells were washed three times and FITC-conjugated anti-mouse Ig (1:200; Cappel, ICN Biomedicals, Milan, Italy) was applied for $1 \mathrm{hr}$ at room temperature to visualize the labeled sites. Nuclei were stained with propidium iodide $(50 \mu \mathrm{g} / \mathrm{ml})$ in PBS. Fluorescence was detected by a Zeiss (Oberkochen, Germany) LSM510 laser scanner microscope.

Reverse transcriptase-PCR analysis of GD3 synthase. Total RNA was extracted from cultures of primary cortical neurons essentially as described previously (Auffray and Rougeon, 1980), except that cells were washed twice with ice-cold PBS and then scraped in $2 \mathrm{ml}$ of cold $3 \mathrm{M}$ $\mathrm{LiCl} / 6 \mathrm{M}$ urea and the procedure was scaled down appropriately. Finally, total RNA was subjected to DNase I treatment (Boehringer Mannheim, Indianapolis, IN) according to the manufacturer's instructions. Two micrograms of total RNA were then used for cDNA synthesis, using Superscript II (Invitrogen, San Diego, CA) and an oligo(dT) primer according to the manufacturer's instructions. The reverse transcriptase (RT) product was diluted to $100 \mu \mathrm{l}$ with sterile, distilled water, and $1 \mu \mathrm{l}$ of cDNA was used in each subsequent PCR amplification. Amplification of GD3 synthase cDNA was performed using the following primers: forward (5'-CCAGCATAATTCGCCAGAGA-3') and reverse (5'TTGCATGTTCACGGAGAAGG-3'). For $\beta$-actin cDNA amplification, the primers were those described by Roelen et al. (1994), which span an intron and yield products of different sizes depending on whether cDNA or genomic DNA is used as a template (400 bp for a cDNA-derived product and $600 \mathrm{bp}$ for a genomic DNA-derived amplification). Reaction conditions included an initial denaturation step $\left(94^{\circ} \mathrm{C}\right.$ for $\left.3 \mathrm{~min}\right)$ followed by 45 cycles of $94^{\circ} \mathrm{C}$ for $30 \mathrm{sec}, 55^{\circ} \mathrm{C}$ for $30 \mathrm{sec}$, and $72^{\circ} \mathrm{C}$ for $30 \mathrm{sec}$. A final extension step $\left(72^{\circ} \mathrm{C}\right.$ for $\left.10 \mathrm{~min}\right)$ concluded the reaction. PCR products (one-third of the reaction) were analyzed electrophoretically on $2 \%$ agarose gels poured and run in $1 \times$ Tris acetate-EDTA.

\section{RESULTS}

We have shown previously that $\beta \mathrm{AP}(1-42)$ or its active fragments $\beta \mathrm{AP}(1-40)$ and $\beta \mathrm{AP}(25-35)$ reactivate the cell cycle and induce apoptotic death in pure cultures of cortical neurons (Copani et al., 1999). Because identical effects were seen with the three peptides,
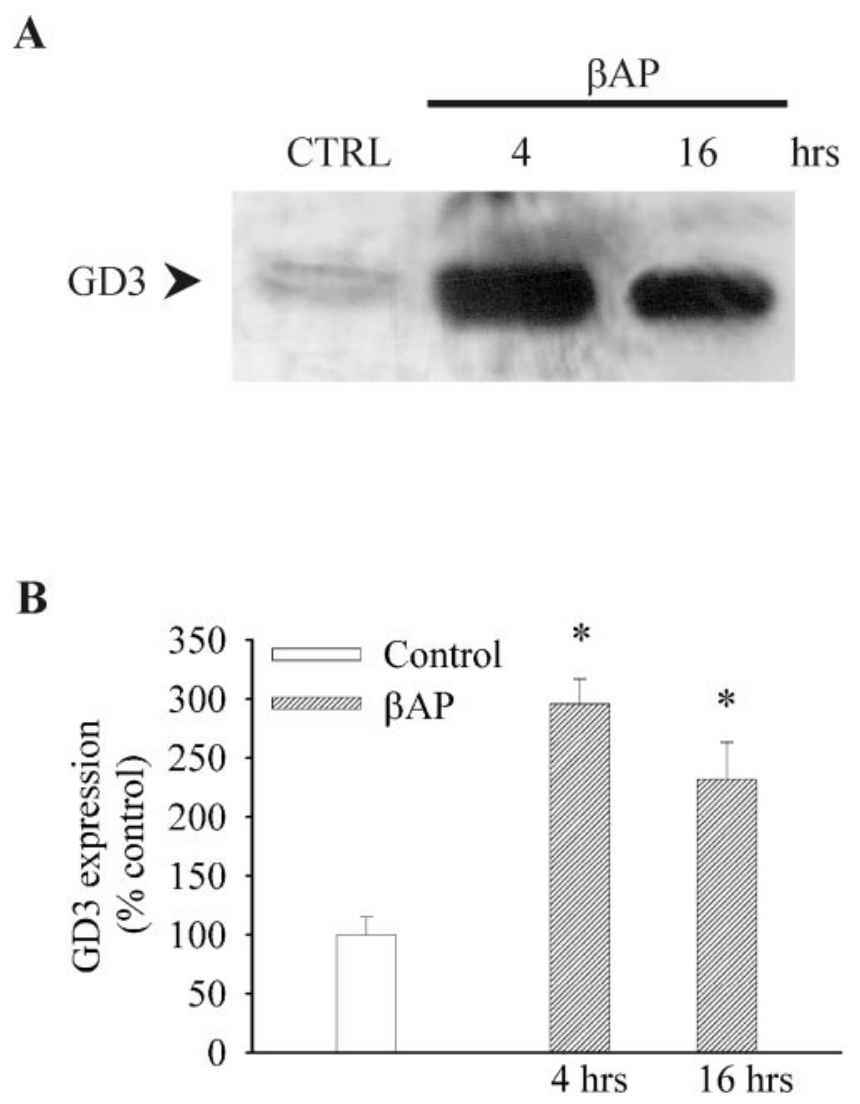

Figure 1. Intracellular GD3 levels in cultured cortical neurons exposed to $\beta \mathrm{AP}(25-35)$ for 4 or $16 \mathrm{hr}$. $A$, A representative TLC stained with anti-GD3 antibodies. $B$, A densitometric analysis of three independent experiments. Four culture dishes $\left(2 \times 10^{6}\right.$ neurons per dish $)$ were pooled for each condition in any experiment. Values are expressed as percentages of controls and represent means \pm SEM. ${ }^{*} p<0.05$ (one-way ANOVA plus Fisher's least significant difference) versus controls. 

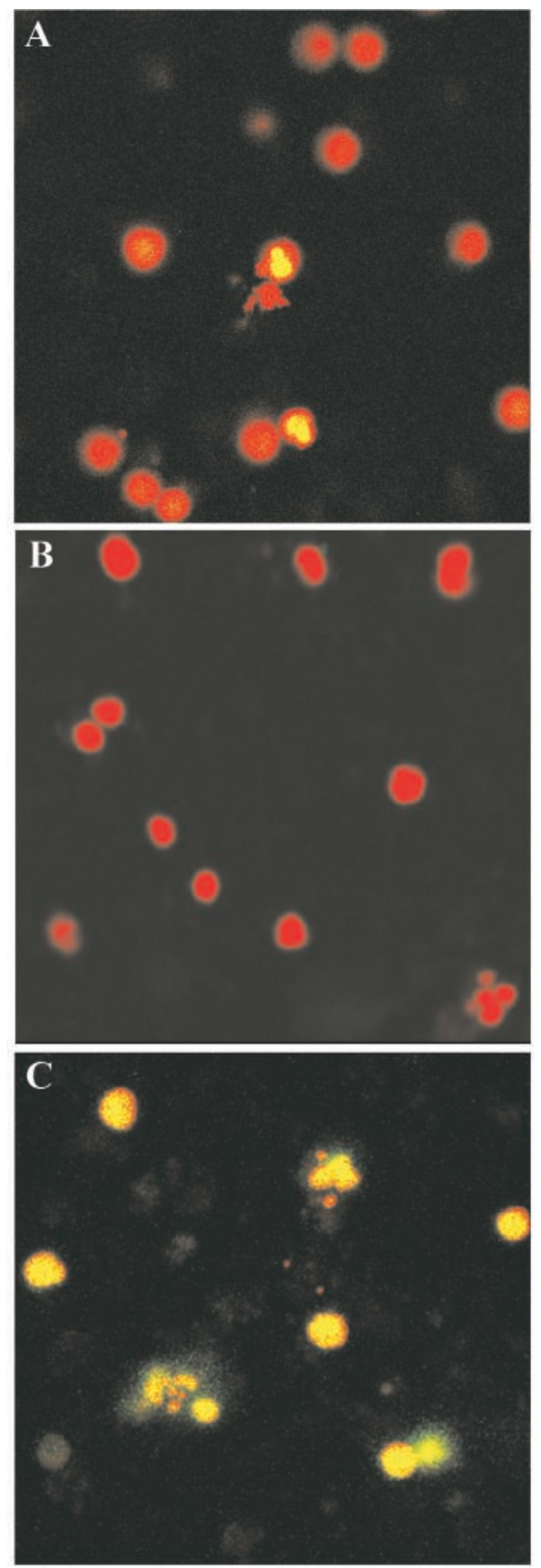

D

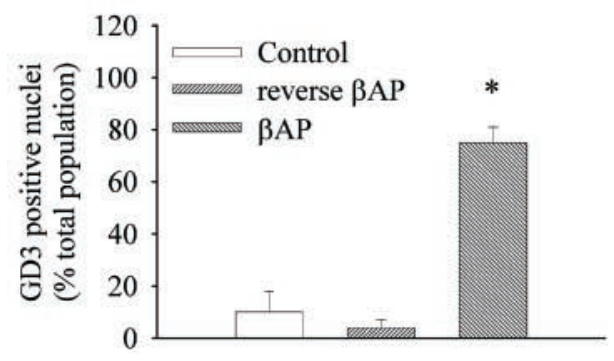

Figure 2. Immunofluorescence analysis of GD3 in control cultures $(A)$ and in cultures exposed to reverse $\beta \mathrm{AP}(35-25)(B)$ or to $\beta \mathrm{AP}(25-35)(C)$ for $16 \mathrm{hr}$. GD3 immunofluorescence is in green. Fluorescence staining of DNA with propidium iodide is in red. Colocalization between GD3 and DNA is in yellow. The count of GD3-positive nuclei is shown in $D$. Values
A

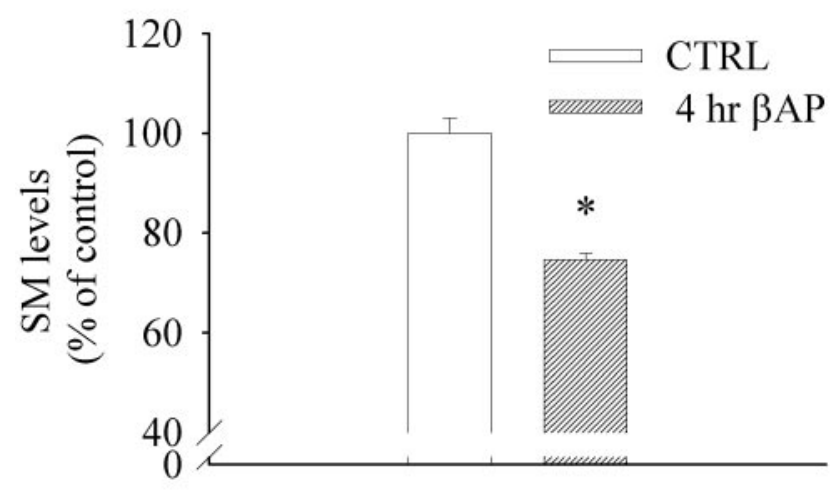

B

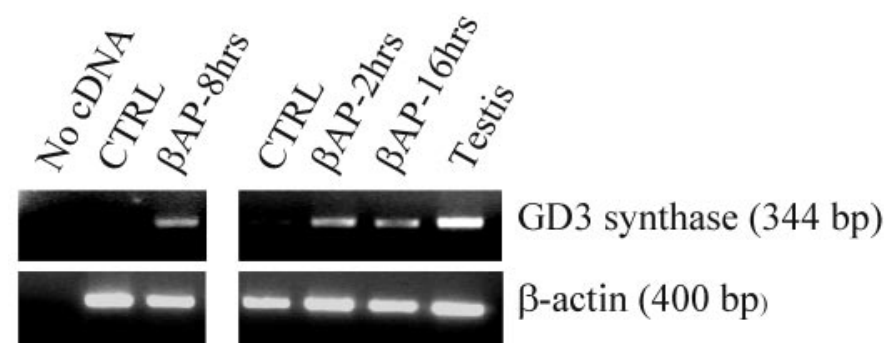

Figure 3. A, Exposure of cultured cortical neurons to $\beta \mathrm{AP}(25-35)$ for 4 hr reduces sphingomyelin $(S M)$ levels. Values are means \pm SEM of five individual determinations. ${ }^{*} p<0.01$ (Student's $t$ test) compared with control cultures. $B$, Expression of GD3 synthase in primary cultures of rat cortical neurons exposed to $\beta \mathrm{AP}(25-35)$ for the indicated times. The results of two representative experiments are shown. CTRL, Control cultures. Amplification of $\beta$-actin cDNA was performed to confirm the integrity of the cDNA preparations and to control for genomic DNA contamination. The $600 \mathrm{bp}$ of $\beta$-actin was not detected, thus excluding any genomic contamination.

we used $\beta \mathrm{AP}(25-35)$ in the present study. $\beta \mathrm{AP}(25-35)(25 \mu \mathrm{M})$ was applied to mature cultures (8-9 DIV) in the presence of a mixture of ionotropic glutamate receptor antagonists $(10 \mu \mathrm{M}$ MK-801 plus $10 \mu \mathrm{M}$ DNQX) to avoid any endogenous excitotoxic component (Copani et al., 1999). As expected, $\sim 8-10 \%$ of cultured neurons were found in $\mathrm{S}$ phase $16 \mathrm{hr}$ after the addition of $\beta A P(25-35)$, whereas no $\mathrm{S}$ phase was seen at earlier times (4 or 8 $\mathrm{hr})$. The number of apoptotic neurons increased progressively after $16 \mathrm{hr}$, reaching $>50 \%$ of the cell population at $20 \mathrm{hr}$ (see also Copani et al., 1999).

TLC analysis combined with immunodetection showed a large increase in GD3 content $4 \mathrm{hr}$ after the addition of $\beta \mathrm{AP}(25-35)$ (i.e., at a time that precedes both neuronal entry into $\mathrm{S}$ phase and

$\leftarrow$

were calculated by a blinded observer from three random fields per culture dish for a total of four to six culture dishes per condition in two to three independent experiments. Each single dish has been considered as an individual value in the statistical analysis (i.e., $n=4-6)$. Values are means \pm SEM. ${ }^{*} p<0.05$ (one-way ANOVA plus Fisher's least significant difference) versus controls or reverse $\beta \mathrm{AP}(35-25)$. Reverse $\beta \mathrm{AP}(35-25)$ was not toxic in these experiments. 


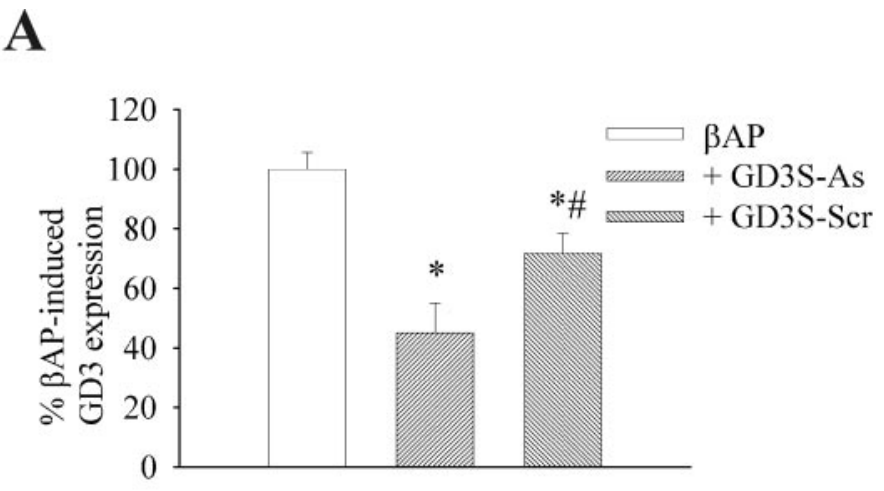

B

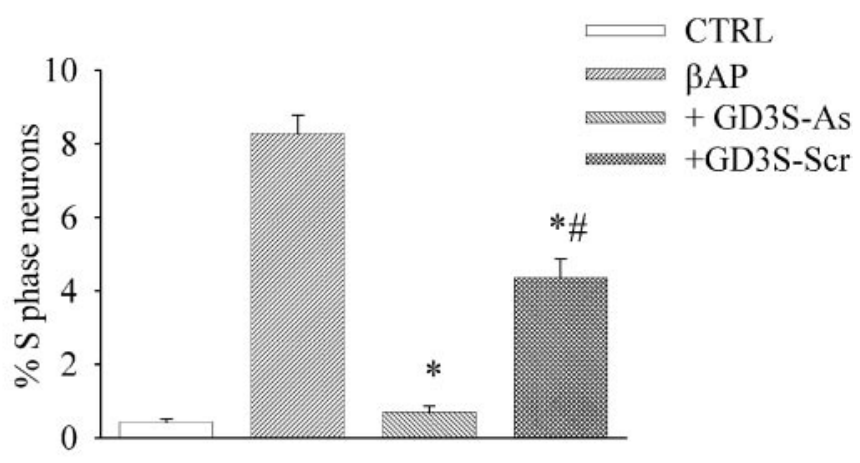

C

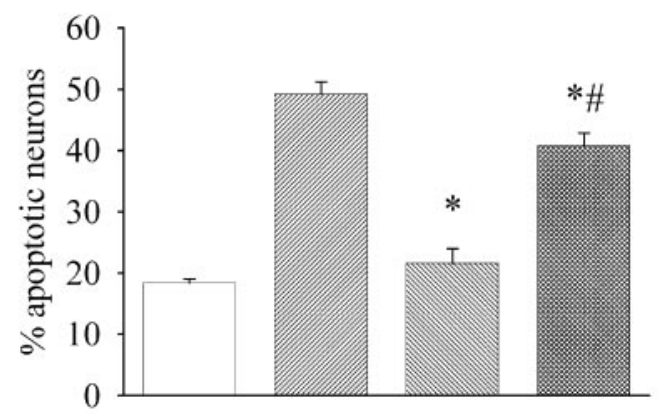

Figure 4. Intracellular GD3 levels $(A)$, percentage of neurons in the $\mathrm{S}$ phase of the cell cycle $(B)$, and percentage of apoptotic neurons $(C)$ in cultured cortical neurons pretreated for $16 \mathrm{hr}$ with GD3 synthase antisense oligonucleotides $(G D 3 S-A s, 3 \mu \mathrm{M})$ or a scrambled oligonucleotide (GD3S-Scr, $3 \mu \mathrm{M})$, and then exposed to $\beta \mathrm{AP}(25-25)$ for $4 \mathrm{hr}(A)$ or $20 \mathrm{hr}$ $(B, C)$. Densitometric analysis of GD3 levels from three independent experiments is shown in $A$. Four culture dishes $\left(2 \times 10^{6}\right.$ neurons per dish) were pooled for each condition in any experiment. Values in $B$ and $C$ were calculated from eight individual culture dishes from three independent experiments. Each single dish has been considered as an individual value in the statistical analysis (i.e., $n=8$ ). $p<0.05$ (one-way ANOVA plus Fisher's least significant difference) if compared with cultures treated with $\beta \mathrm{AP}(25-35)$ alone (*) or with $\beta \mathrm{AP}$ plus GD3S-As (\#).

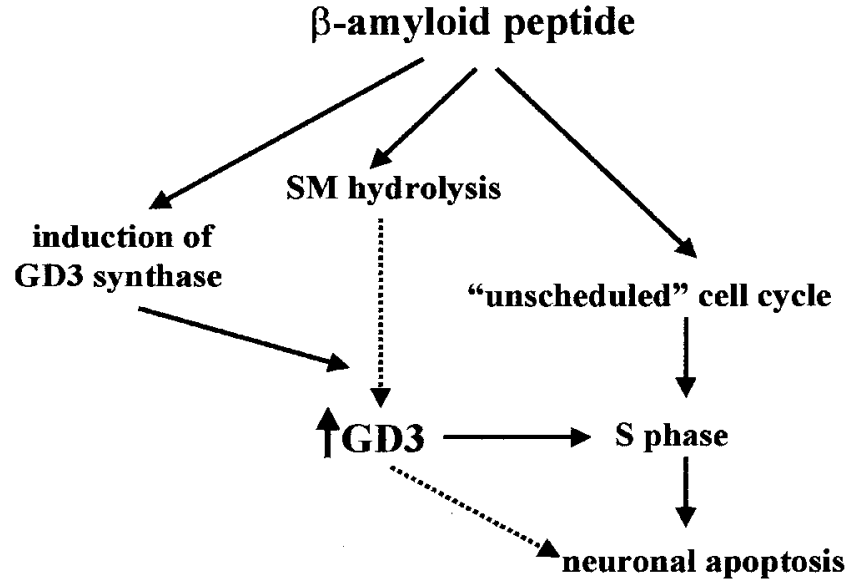

Figure 5. Hypothetical model of the role of GD3 in $\beta$ AP-induced cell-cycle activation and apoptosis. $S M$, Sphingomyelin.

apoptotic death) (Fig. 1). GD3 levels decreased, but were still higher than in control cultures, $16 \mathrm{hr}$ after the addition of $\beta \mathrm{AP}(25-35)$ (Fig. 1A,B).

In Figure $2 A, B, D$, double-fluorescence analysis of GD3 ( green) and nuclear chromatin (red) showed few neurons expressing GD3 in control cultures or in cultures exposed to the reverse peptide $\beta A P(35-25)$. Nearly all neurons became immunopositive for GD3 in neurons exposed to $\beta \mathrm{AP}(25-35)$. Immunoreactivity was mostly detected in cell nuclei (yellow) after the addition of $\beta A P(25-35)$, although it was also found outside the nuclear region in late degenerating neurons (Fig. 2C,D).

The early increase in GD3 expression paralleled a reduction of the sphingomyelin content in neurons exposed to $\beta \mathrm{AP}(25-35)$ for $4 \mathrm{hr}$ (Fig. 3A), suggesting that GD3 is synthesized after $\beta \mathrm{AP}(25-$ 35)-induced sphingomyelin hydrolysis. RT-PCR analysis showed that $\beta \mathrm{AP}(25-35)$ induced the expression of GD3 synthase mRNA after 2,8 , and $16 \mathrm{hr}$ (Fig. 3B).

To examine whether the increase in GD3 levels was causally related to the reactivation of the cell cycle and apoptotic death induced by $\beta \mathrm{AP}$, we treated the cultures with a $3 \mu \mathrm{M}$ concentration of end-capped antisense oligonucleotides directed against GD3 synthase for $16 \mathrm{hr}$ before the addition of $\beta \mathrm{AP}(25-35)$. GD3 synthase antisense oligonucleotides substantially reduced the rise of neuronal GD3 content induced by $\beta \mathrm{AP}(25-35)$ at $4 \mathrm{hr}$, whereas a scrambled oligonucleotide had a smaller effect (Fig. 4A). Cytofluorometric analysis showed that GD3 synthase antisense oligonucleotides abolished the neuronal re-entry into the $\mathrm{S}$ phase of the cell cycle in response to $\beta \mathrm{AP}(25-35)$ (Fig. $4 B$ ) and substantially protected against $\beta \mathrm{AP}(25-35)$-induced apoptosis (Fig. $4 C$ ). Scrambled oligonucleotides could also reduce $\beta \mathrm{AP}(25-35)$ induced $\mathrm{S}$ phase and apoptosis, but their effect was much smaller and was significantly different from that produced by GD3 synthase antisense oligonucleotides (Fig. 4B,C).

Together, these results indicate that $\beta \mathrm{AP}(25-35)$-induced GD3 synthesis is antecedent and causally related to neuronal cell-cycle reactivation and apoptosis.

\section{DISCUSSION}

After the induction of apoptosis, GD3 accumulates in nonneuronal cells, where it contributes to the death pathway by a dual mechanism that involves the opening of mitochondrial permeability transition pores and the suppression of the nuclear factor- $\kappa \mathrm{B}-$ dependent survival pathway (De Maria et al., 1997; Kristal and 
Brown, 1999; Malisan and Testi, 1999; Scorrano et al., 1999; Rippo et al., 2000; Colell et al., 2001). In neurons, a number of studies have been performed with exogenously added gangliosides (Favaron et al., 1988; Manev et al., 1990; Saito et al., 1998, 1999; Ryu et al., 1999), but the functional role of endogenously generated gangliosides in neurodegenerative processes has never been investigated.

In this study, we show that GD3 accumulates in rat cortical neurons that have been exposed to $\beta \mathrm{AP}(25-35)$. We have demonstrated previously that mature neurons must re-enter the cell cycle and cross the $\mathrm{G}_{1} / \mathrm{S}$ transition before undergoing $\beta A P$ induced apoptosis (Copani et al., 1999). $\beta A P$-treated cortical neurons express a battery of proteins that are typically expressed by proliferating cells during $G_{1} / S$ phases, such as cyclin D1, phosphoretinoblastoma, cyclin E, and cyclin A. Neurons eventually enter the $\mathrm{S}$ phase, as shown by quantitative cytofluorometric analysis, and then die by apoptosis before crossing the border between the $\mathrm{S}$ and $\mathrm{G}_{2}$ phases (Copani et al., 1999). The use of a dexamethasone-inducible cyclin D1 mRNA antisense, a negative dominant mutant of cyclin-dependent kinase type 2 (CDK2) or chemical CDK inhibitors has shown that the unscheduled cell cycle is causally related to apoptotic death in neurons exposed to $\beta$ AP (Copani et al., 1999, 2001). These in vitro studies have their in vivo counterpart in the AD brain, in which Yang et al. (2001) provided evidence for chromosomal replication in "at-risk" neurons. The present data indicate that GD3 is an essential component of the signaling pathway(s) leading to the reactivation of the cell cycle in $\beta$ AP-treated neurons (Fig. 5). This evidence is consistent with the regulatory functions of GD3 in cellular proliferation and differentiation processes. PC12 cells overexpressing the GD3 synthase gene showed an enhanced rate of proliferation attributable to a sustained activation of the Ras/mitogenactivated protein-extracellular signal-regulated kinase kinase/ extracellular signal-regulated kinase pathway and failed to differentiate in response to NGF (Fukumoto et al., 2000). In malignant cells, GD3 induces the suppression of differentiation phenotypes and promotes proliferation (Sottocornola et al., 1998; Birkle et al., 2000).

In neurons that degenerate in response to $\beta \mathrm{AP}$, neosynthesized GD3 accumulated inside the nuclear region and colocalized with nuclear chromatin. In other cell types, in which apoptosis is not associated with a reactivation of the cell cycle, GD3 is instead consistently found outside the nucleus (Malisan and Testi, 1999). To date, only gangliosides of the "a" series have been described in the cell nucleus. GM1 is found in the nuclear membrane, where its expression is upregulated during axonogenesis (Wu et al., 1995, 2001; Kozireski-Chuback et al., 1999). Interestingly, GM1 inhibits DNA synthesis and the activity of DNA polymerase $\alpha$ in isolated nuclei of HeLa cells (Ohsawa et al., 1988). An attractive hypothesis is that GD3 acts as a functional counterpart of GM1 by increasing cell proliferation via a nuclear mechanism. Accordingly, in neurons exposed to $\beta \mathrm{AP}, \mathrm{GD} 3$ might provide a nuclear signal for the aberrant DNA replication. The evidence that the antisense-induced decrease in GD3 levels was highly effective in preventing the unscheduled $\mathrm{S}$ phase, and the ensuing apoptotic phenotype strengthens the hypothesis of a causal relationship among GD3 formation, cell-cycle activation, and neuronal death. However, we cannot exclude the possibility that GD3 contributes to $\beta \mathrm{AP}$-induced apoptosis through additional mechanisms (Fig. 5), for example by targeting the mitochondrial pathway of cell death.
Ceramide released from sphingomyelin hydrolysis is a likely source for GD3 synthesis (De Maria et al., 1998). Sphingomyelin hydrolysis might follow the interaction of $\beta \mathrm{AP}$ aggregates with a membrane receptor, the identity of which is unknown. The p75 low-affinity neurotrophin receptor is a possible candidate (Yaar et al., 1997), because this receptor has been shown to transduce the extracellular signal via the activation of acidic sphingomyelinase (Brann et al., 1999; Bilderback et al., 2001). The finding of an early induction of GD3 synthase in response to $\beta A P$ is particularly interesting because it provides the first evidence that this enzyme is upregulated in response to a death signal. This suggests a novel strategy against $\beta \mathrm{AP}$-induced neurotoxicity based on the pharmacological regulation of GD3 synthase expression.

\section{REFERENCES}

Ando S, Toyoda Y, Nagai Y, Ikuta F (1984) Alterations in brain gangliosides and other lipids of patients with Creutzfeldt-Jakob disease and subacute sclerosing panencephalitis (SSPE). Jpn J Exp Med 54:229-234.

Arendt T, Holzer M, Gartner U, Bruckner MK (1998) Aberrancies in signal transduction and cell cycle related events in Alzheimer's disease. J Neural Transm 54:147-158.

Auffray C, Rougeon F (1980) Purification of mouse immunoglobulin heavy-chain messenger RNAs from total myeloma tumor RNA. Eur J Biochem 107:303-314.

Behl C (2000) Apoptosis in Alzheimer's disease. J Neurol Transm 107:1325-1344.

Bilderback TR, Gazula VR, Dobrowsky R (2001) Phosphoinositide 3-kinase regulates crosstalk between Trk A tyrosine kinase and p75(NTR)-dependent sphingolipid signaling pathways. J Neurochem 76:1540-1551.

Birkle S, Gao L, Zeng G, Yu RK (2000) Down regulation of GD3 ganglioside and its $O$-acetylated derivative by stable transfection with antisense vector against GD3-synthase gene expression in hamster melanoma cells: effects on cellular growth, melanogenesis, and dendricity. J Neurochem 75:547-554.

Brann AB, Scott R, Neuberger Y, Abulafia D, Boldin S, Fainzilber M, Futerman AH (1999) Ceramide signaling downstream of the p75 neurotrophin receptor mediates the effects of nerve growth factor on outgrowth of cultured hippocampal neurons. J Neurosci 19:8199-8206.

Busser J, Geldmacher DS, Herrup K (1998) Ectopic cell cycle proteins predict the sites of neuronal cell death in Alzheimer's disease brain. J Neurosci 18:2801-2807.

Colell A, Garcia-Ruiz C, Roman J, Ballesta A, Fernandez-Checa JC (2001) Ganglioside GD3 enhances apoptosis by suppressing the nuclear factor- $\kappa$ B-dependent survival pathway. FASEB J 15:1068-1070.

Copani A, Condorelli F, Caruso A, Vancheri C, Sala A, Giuffrida Stella AM, Canonico PL, Nicoletti F, Sortino MA (1999) Mitotic signaling by $\beta$-amyloid causes neuronal death. FASEB J 13:2225-2234.

Copani A, Uberti D, Sortino MA, Bruno V, Nicoletti F, Memo M (2001) Activation of cell-cycle-associated proteins in neuronal death: a mandatory or dispensable path? Trends Neurosci 24:25-31.

De Maria R, Lenti L, Malisan F, d'Agostino F, Tomassini B, Zeuner A, Rippo MR, Testi R (1997) Requirement for GD3 ganglioside in CD95- and ceramide-induced apoptosis. Science 277:1652-1655.

De Maria R, Rippo MR, Schuchman EH, Testi R (1998) Acidic sphingomyelinase (ASM) is necessary for fas-induced GD3 ganglioside accumulation and efficient apoptosis in lymphoid cells. J Exp Med 187:897-902.

Dotta F, Previti M, Neerman-Arbez M, Dionisi S, Cucinotta D, Lenti L, Di Mario U, Halban PA (1998) The GM2-1 ganglioside islet autoantigen in insulin-dependent diabetes mellitus is expressed in secretory granules and is not beta-cell specific. Endocrinology 139:316-319.

Favaron M, Manev H, Alho H, Bertolino M, Ferret B, Guidotti A, Costa $\mathrm{E}$ (1988) Gangliosides prevent glutamate and kainate neurotoxicity in primary neuronal cultures of neonatal rat cerebellum and cortex. Proc Natl Acad Sci USA 85:7351-7355.

Forloni G, Chiesa R, Smiroldo S, Verga L, Salmona M, Tagliavini F, Angeretti N (1993) Apoptosis mediated neurotoxicity induced by chronic application of $\beta$-amyloid 25-35. NeuroReport 4:523-526.

Fukumoto S, Mutoh T, Hasegawa T, Miyazaki H, Okada M, Goto J, Furukawa K, Urano T (2000) GD3 synthase gene expression in PC12 cells results in the continuous activation of TrkA and ERK1/2 and enhanced proliferation. J Biol Chem 275:5832-5838.

Giovanni A, Wirtz-Brugger F, Keramaris E, Slack R, Park DS (1999) Involvement of cell cycle elements, cyclin-dependent kinases, $\mathrm{pRb}$, and $\mathrm{E} 2 \mathrm{~F} \times \mathrm{DP}$, in $\beta$-amyloid-induced neuronal death. J Biol Chem 274:19011-19016.

Giovanni A, Keramaris E, Morris EJ, Hou ST, O’Hare M, Dyson N, 
Robertson GS, Slack RS, Park DS (2000) E2F1 mediates death of $\beta$-amyloid-treated cortical neurons in a manner independent of $\mathrm{p} 53$ and dependent on Bax and caspase 3. J Biol Chem 275:11553-11560.

Goldman JE, Reynolds R (1996) A reappraisal of ganglioside GD3 expression in the CNS. Glia 16:291-295.

Herrup K, Busser JC (1995) The induction of multiple cell cycle events precedes target-related neuronal death. Development 121:2385-2395.

Joseph J, Shukitt-Hale B, Denisova NA, Martin A, Perry G, Smith MA (2001) Copernicus revisited: amyloid beta in Alzheimer's disease. Neurobiol Aging 22:131-146.

Kalanj S, Kracun I, Rosner H, Cosovic C (1991) Regional distribution of brain gangliosides in Alzheimer's disease. Neurol Croat 40:269-281.

Kawai H, Sango K, Mullin KA, Proia RL (1998) Embryonic stem cells with a disrupted GD3 synthase gene undergo neuronal differentiation in the absence of b-series gangliosides. J Biol Chem 273:19634-19638.

Kozireski-Chuback D, Wu G, Ledeen RM (1999) Axogenesis in neuro-2a cells correlates with GM1 upregulation in the nuclear and plasma membranes. J Neurosci Res 57:541-550.

Kristal BS, Brown AM (1999) Apoptogenic GD3 directly induces the mitochondrial permeability transition. J Biol Chem 274:23169-23175.

Loo DT, Copani A, Pike CJ, Whittemore ER, Walencewicz AJ, Cotman CW (1993) Apoptosis is induced by beta-amyloid in cultured central nervous system neurons. Proc Natl Acad Sci USA 90:7951-7955.

Malisan F, Testi R (1999) Lipid signaling in CD95-mediated apoptosis. FEBS Lett 452:100-103.

Manev H, Favaron M, Vicini S, Guidotti A, Costa E (1990) Glutamateinduced neuronal death in primary cultures of cerebellar granule cells: protection by synthetic derivatives of endogenous sphingolipids. J Pharmacol Exp Ther 252:419-427.

Mattson MP (2000) Apoptosis in neurodegenerative disorders. Nat Rev Mol Cell Biol 1:120-129.

McShea A, Wahl AF, Smith MA (1999) Re-entry into the cell cycle: a mechanism for neurodegeneration in Alzheimer disease. Med Hypotheses 52:525-527.

Nagy Z, Esiri MM, Smith AD (1998) The cell division cycle and the pathophysiology of Alzheimer's disease. Neuroscience 87:731-739.

Ohsawa T, Ikeda H, Senshu T (1988) Effects of ganglioside GM1 on DNA synthesis in isolated nuclei and on the activity of DNA polymerase alpha derived from S-phase HeLa cells. Biochim Biophys Acta 949:305-310.

Percy AK, Gottfries J, Vilbergsson G, Mansson JE, Svennerholm L (1991) Glycosphingolipid glycosyltransferases in human fetal brain. J Neurochem 56:1461-1465.

Rippo MR, Malisan F, Ravagnan L, Tomassini B, Condo I, Costantini P, Susin SA, Rufini A, Todaro M, Kroemer G, Testi R (2000) GD3 ganglioside directly targets mitochondria in a bcl-2-controlled fashion. FASEB J 14:2047-2054.
Roelen BA, Lin HY, Knezevic V, Freund E, Mummery CL (1994) Expression of TGF- $\beta$ s and their receptors during implantation and organogenesis of the mouse embryo. Dev Biol 166:716-728.

Roth KA (2001) Caspases, apoptosis, and Alzheimer disease: causation, correlation and confusion. J Neuropathol Exp Neurol 60:829-838.

Ryu BR, Choi DW, Hartley DM, Costa E, Jou I, Gwag BJ (1999) Attenuation of cortical neuronal apoptosis by gangliosides. J Pharmacol Exp Ther 290:811-816.

Saito M, Guidotti A, Berg MJ, Marks N (1998) The semisynthetic ganglioside LIGA20 potently protects neurons against apoptosis. Ann NY Acad Sci 845:253-262.

Saito M, Berg MJ, Guidotti A, Marks N (1999) Gangliosides attenuate ethanol-induced apoptosis in rat cerebellar granule neurons. Neurochem Res 24:1107-1115.

Scorrano L, Petronilli V, Di Lisa F, Bernardi P (1999) Commitment to apoptosis by GD3 ganglioside depends on opening of the mitochondrial permeability transition pore. J Biol Chem 274:22582-22585.

Selkoe DJ (2001) Alzheimer's disease: genes, proteins, and therapy. Physiol Rev 81:741-766.

Small DH, Mok SS, Bornstein JC (2001) Alzheimer's disease and Abeta toxicity: from top to bottom. Nat Rev Neurosci 2:595-598.

Sottocornola E, Colombo I, Vergani V, Taraboletti G, Berra B (1998) Increased tumorigenicity and invasiveness of $\mathrm{C} 6$ rat glioma cells transfected with the human $\alpha-2,8$ sialyltransferase cDNA. Invasion Metastasis $18: 142-154$.

Svennerholm L, Fredman P (1980) A procedure for the quantitative isolation of brain gangliosides. Biochim Biophys Acta 617:97-109.

Svennerholm L, Rynmark BM, Vilbergsson G, Fredman P, Gottfries J, Mansson JE, Percy A (1991) Gangliosides in human fetal brain. J Neurochem 56:1763-1768.

Vincent I, Rosado M, Davies P (1996) Mitotic mechanisms in Alzheimer's disease? J Cell Biol 132:413-425.

Wu G, Lu ZH, Ledeen RW (1995) GM1 ganglioside in the nuclear membrane modulates nuclear calcium homeostasis during neurite outgrowth. J Neurochem 65:1419-1422.

Wu G, Lu ZH, Xie X, Ledeen R (2001) Comparison of ganglioside profiles in nuclei and whole cells of NG-108 and NG-CR72 lines: changes in response to different neuritogenic stimuli. Brain Res Dev Brain Res 126:183-190.

Yaar M, Zhai S, Pilch PF, Doyle SM, Eisenhauer PB, Fine RE, Gilchrest BA (1997) Binding of $\beta$-amyloid to the p75 neurotrophin receptor induces apoptosis: a possible substrate for Alzheimer's disease. J Clin Invest 100:2333-2340.

Yang Y, Geldmacher DS, Herrup K (2001) DNA replication precedes neuronal cell death in Alzheimer's disease. J Neurosci 21:2661-2668. 